Forum: Building a Better Adult Basic Skills Development System

(Part 3 of 3)

\title{
Response to Paul J. Jurmo
}

\begin{abstract}
Art Ellison, Former N.H. State Director of Adult Education, Member of the N.H. House Education Committee
\end{abstract}

Paul Jurmo's “Ten Actions to Build an Adult Basic Skills Development System That is More Inclusive, Relevant, Efficient and Sustained" reviews the recent history of the adult education field and then sets out 10 actions that would substantially improve the delivery system for adult education services in this country.

My reactions to the Paul's action steps are informed by 38 years as the New Hampshire State Director of Adult Education and 2 years as a member of the New Hampshire House serving on the Education Committee.

As Paul says the "idea of building bettercoordinated systems of services" is not new. Adult educators have struggled with that concept for much of the last 40 years. This issue has come into even more focus in the last six years with the emphasis in federal adult education legislation (Workforce Innovation and Opportunity Act [WIOA] of 2014) focusing adult education funding on workforce training. This change left some in the adult education community fighting for a concept of adult education that is much broader than that contained in the new federal law.

An example of this movement can be seen in the Integrated Education and Training portion of WIOA. This title replaced the English Language Civics title in the earlier legislation (Workforce Investment Act of 1994). This section of the law was funded with about $12 \%$ of the adult education yearly appropriation. Under the English Language Civics portion of WIA adult education programs developed high quality civic literacy programs (as Paul notes in 2. Re-define those we serve and how basic skills limitations can impact them) that helped students become involved in their communities by understanding how policies were made in their local community and how they could participate in that process. Under WIOA that aspect of the English Language Civics program was greatly reduced in favor of workforce training.

The excellent Equipped for the Future (EFF) (Spangenberg \& Watson, 2003) project that Paul mentions as part of expanding how learners can develop basic skills is a prime example of how the adult education field can conceptualize a major turning point for instruction. However, the reluctance of the field to integrate even separate elements of that work speaks to the difficulty that arises with institutions/funding sources and the field as a whole to what would be a huge expansion of the goals and practice of adult education. In fact, as I noted above with the example of EL Civics and Integrated Education and Training (IET) programs the mission of the field tends to be narrowing rather than expanding.

Paul's focus on the need to recognize the strengths of adult education students should be a guiding principle for all adult educators. While students 
come to programs with some very specific learning needs we must understand their strengths and provide the setting for them to grow as well.

Many of Paul's well thought out actions would call for a significant increase in adult education funding (i.e., recognize adult basic skills education as a profession, expand when, where and how learners can develop basic skills, take a comprehensive view of basic skills, recognizing adult basic skills education as a profession) which brings us to the age old elephant in the room for adult educators: there is not enough money in the system to carry out the work that would move adult education into a much more prominent place in the education universe of our country.

That is not to say that we have not made some progress (New Hampshire is considering a law to open up its state funded Job Training Fund to adult education programs and other states have been successful in working with job training partner organizations) but the very real needs that Paul lays out will require an unprecedented movement by the entire adult education community that focuses on the policy-making institutions on the state and federal levels.

Given the resources that will be needed to implement Paul's Ten Actions, I have listed some major recommendations relating to advocacy that could be used to carry out that work.

\section{The Power of Student Advocates}

State advocacy campaigns for adult education funding that focus on student involvement have been very successful in some states and cities. Massachusetts, New Hampshire, Arizona, Los Angeles, New York City, Minnesota, and Pennsylvania have done some excellent work in this regard. Student led advocacy campaigns are almost always more successful than those conceived and carried out by adult educators alone.

Student focused advocacy campaigns not only develop and amplify student voices for the ongoing campaign but their participation gives them tools and skills that will be used throughout their lives as they strive to take control of the institutions with which they will interact.

\section{The Impact of Student Voices on Policy Makers}

State and federal policy makers, particularly those in political office, respond to their constituents, which in this case are adult students. While research studies and statistical reports may have some place in an advocacy campaign they will always pale when compared to the power of constituent voices.

Student voices are always communicated to policy makers through personal stories. The format for student communications has always been: a description of why the student enrolled in the program, what they will do when they finish and a request (the ask) of "support adult education," or "support more funding for adult education."

As a state legislator, I receive thousands of letters/emails asking me to support a particular action. Over $98 \%$ of them are form letters from lobbying groups that are sent by their members. On the opening day of the New Hampshire House Education Committee last year, the Chair informed all of the members that the "only individualize communications that you receive will be from adult education students and there will be lots of them."

\section{Adult Educators as Advocates}

In general adult educators are uncomfortable with the concept of advocacy, particularly when it takes 
on a political focus, as it almost always does. Some of this hesitancy may be linked to the federal adult education policy makers, who take a negative view of even voter registration activities, but it is also related to the lack of political awareness of many staff. In this regard we must all be encouraged by the number of states where recently teachers have risen up to confront policy makers over issues of pay, classroom teaching conditions and overall funding for schools, indicating that they understand they are willing to advocate for their needs and the needs of their students.

\section{The Focus of Advocacy Campaigns}

Advocacy efforts should be focused on the state level since $75 \%$ of funding for adult education programs comes from the states. An additional benefit of this funding pattern is that state adult education funds do not need to follow WIOA regulations. A number of states have begun disconnecting their state adult education funded programs from those funded with WIOA money. This allows them much more flexibility in program design and practice. New York state is a good example.

The roadmap that Paul has laid out is comprehensive and if followed would move adult education into the forefront of adult learning in our country. In order to make that happen there is a need for a massive campaign, led by inspired adult educators and hundreds of thousands of students that will focus on the institutions that could provide the resources to make Paul's vision come true. 


\section{References}

Spangenberg, G., \& Watson, S. (2003). Equipped for the future: Tools and standards for building and assessing quality adult literacy programs. New York, NY: Council for Advancement of Adult Literacy.

Workforce Innovation and Opportunity Act, Public Law No. 113-128, 113th Congress, 2nd Session. (22 July 2014). Retrieved from https://www.gpo.gov/fdsys/pkg/ PLAW113publ128/pdf/PLAW-113publ128.pdf
Workforce Investment Act of 1998. Department of Labor. Retrieved from http://www.doleta.gov/usworkforce/ wia/wialaw.pdf 